\title{
Multiple Water Use in Gardenland Integrated Farming System for Enhancing Productivity
}

\author{
J. Bhuvaneswari ${ }^{1}$, G. Thiyagarajan ${ }^{2 *}$, M. Manikandan ${ }^{3}$, \\ S. K. Natarajan ${ }^{4}$ and S. Thenmozhi ${ }^{5}$
}

${ }^{1}$ Agricultural College and Research Institute, Tamil Nadu Agricultural University, Killikulam, India

${ }^{2}$ Water Technology Centre, ${ }^{4}$ Department of Agronomy, Tamil Nadu Agricultural University, Coimbatore, India

${ }^{3}$ Agricultural Engineering College and Research Institute, Tamil Nadu Agricultural University, Kumulur, India

${ }^{5}$ Subject Matter Specialist (SS\&SC), Krishi Vigyan Kendra, Tamil Nadu Agricultural University, Pongalur, India

*Corresponding author

\section{A B S T R A C T}

\section{Keywords}

Integrated Farming System,

Gardenland, Water productivity, Yield, economics

Article Info

\section{Accepted:}

15 October 2020

Available Online:

10 November 2020
A model of integrated input management to suit small farmers under garden-land conditions was studied at Agricultural Research Station, Bhavanisagar during 2015 and 2016 in an area of 1 ha. The objective of the study was to achieve better utilization of available resources to maximize returns by integrating cropping, dairy, poultry and vermin-compost, to recycle farm and livestock wastes effectively to assure stability in production and returns. The results over the two year period revealed that by integrating allied enterprises with crop activity, income and productivity can be enhanced. Integrated Farming System recorded lower water consumed $\left(14249 \mathrm{~m}^{3}\right)$ compared to conventional farming system $\left(22925 \mathrm{~m}^{3}\right)$. The higher gross income of Rs.5,62,044/- physical water productivity $\left(8.26 \mathrm{~kg} \mathrm{~m}^{-3}\right)$ and economic water productivity (39.44 Rs. $\mathrm{m}^{-3}$ ) recorded under Integrated Farming System compared to conventional farming system.

\section{Introduction}

Agricultural sector in India has been and is likely to remain the largest consumer of water. The share of water allocated to irrigation is likely to decrease by 10 to $15 \%$ in the coming decades (CWC 2018). Hence, more focus should be on sustainable management of water resources for optimal agricultural production. It is essential to increase the efficiency of each component of irrigation system and crop production, preventing wasteful and ecologically injurious use of water. In view of these considerations, it is largely emphasized for enhancing water productivity through multiple uses. In general, 
multiple use of water is not a new concept. There are examples of several water resource projects simultaneously planned for electricity generation, irrigation, and meeting rural, urban and industrial uses and also naval and transport purposes (Bakker et al., 1999). At the farm level, water can be judiciously applied for multiple uses such as drinking, irrigation, livestock, fisheries etc. to optimize water productivity. Integrated farming system (IFS) based on multiple uses of water, comprising of crop, fishery, duckery, poultry, piggery, agro-forestry etc. are in practice not only in India but also in other Asian countries. Such a system results in more judicious use of water resulting in higher water productivity and also improving livelihood of resource poor farmers (Sharda and Juyal, 2007; Gill et al., 2005). The field experiments were conducted at Agricultural Research Station, Bhavanisagar under ICAR - All India Coordinated Project (AICRP) on Irrigation Water Management project resulted evaluation of Integrated farming system compared to conventional method of farming in gardenland situation.

\section{Materials and Methods}

The IFS for gardenland situation experiments were conducted in Northern block of Agricultural Research Station, Bhavanisagar during 2015 and 2016 under ICAR - AICRP on Irrigation Water Management. The objective of the study was to work out the water requirements for cropping components and livestock components in Integrated Farming System under wetland situation, to assess the multiple use of water by way of estimating water use and water productivity in different components of farming system under wetland situations in western zone of Tamil Nadu. For conventional method Rice Groundnut - Maize were followed in one hectare area. In gardenland Integrated Farming Systems, the experiment details is presented in Table 1. Since it is a farming system experiment it does not involve any specific design and non replicated. Vaccination was done for the poultry birds regularly for Ranikhet disease. Vaccine for Foot and Mouth disease were given for the milch cows once in 6 months.

In integrated farming system, irrigation based on IW/CPE ratio (Table 2) and conventional methods surface irrigation once in 7-10 days were adopted. The major soil type of the study area was sandy loam in nature and the soil fertility status was medium in available nitrogen, phosphorus and potash. Two methods of cultivation viz., Integrated farming system and conventional method were compared.

The total water use was calculated by adding irrigation water applied and effective rainfall. Yield was recorded and total water used, water use efficiency (WUE) and economics were worked out and presented. The rainfall during 2015 and 2016 were $862 \mathrm{~mm}, 236 \mathrm{~mm}$ and pan evaporation were 1644 and $1693 \mathrm{~mm}$ respectively.

\section{Results and Discussion}

\section{Water productivity in integrated farming system}

Output in terms of biological yield per unit of water is termed as water productivity. It varies with scale as well as the purpose for which it is being quantified. The definition of water productivity varies with the background of the researcher or stakeholders involved (Bastiaanssen et al., 2003). Water productivity at field level is the amount of crop output in physical terms i.e. crop yield divided by amount of water consumed (i.e. the crop evapo-transpiration) or monetary terms i.e. crop yield multiplied by its price divided by amount of water used. It accounts for all or one of the inputs of the production system giving rise to two productivity 
indicators: (i) total productivity i.e. the ratio of total tangible outputs divided by total tangible inputs; and (ii) partial or single factor productivity i.e. the ratio of total tangible output to input of one factor within a system (Molden, 1997). Like land productivity, water productivity is also a partial factor productivity that measures how the systems convert water into goods and services (Molden et al., 2003). Its generic equation is:

Water productivity $=\frac{\text { Prodwet output }}{\text { Water inpwt }}$

In gardenland situation, each one hectare area was allocated for Conventional Farming System (CFS) and Integrated Farming System (IFS). From the Table 3, it concluded that the total water consumed in one hectare IFS was lower $\left(14249 \mathrm{~m}^{3}\right)$ compared to conventional farming system $\left(22925 \mathrm{~m}^{3}\right)$. The higher physical water productivity in one hectare IFS $\left(8.26 \mathrm{~kg} \mathrm{~m}^{3}\right)$ compared to conventional farming system $\left(1.62 \mathrm{~kg} \mathrm{~m}^{3}\right)$.

At the farm level, water can be judiciously applied for multiple uses such as drinking, irrigation, livestock, fisheries etc. to optimize water productivity. Integrated farming system (IFS) based on multiple uses of water, comprising of crop, fishery, duckery, poultry, piggery, agro-forestry etc. are in practice not only in India but also in other Asian countries. Such a system results in more judicious use of water resulting in higher water productivity and also improving livelihood of resource poor farmers (Sharda and Juyal, 2007; Gill et al., 2005). An integrated farming system (IFS) in Punjab under shallow water table conditions, the water productivity increased by $56-86 \%$ under IFS in comparison with only rice-wheat system (Gill et al., 2005).

Table.1 Integrated farming system components (1 ha) - gardenland

\begin{tabular}{|l|l|}
\hline \multicolumn{1}{|c|}{ Components } & \multicolumn{2}{c|}{ Area } \\
\hline Sugarcane & $2000 \mathrm{~m}^{2}$ \\
\hline Banana & $2000 \mathrm{~m}^{2}$ \\
\hline Turmeric & $2000 \mathrm{~m}^{2}$ \\
\hline Maize - Fodder sorghum & $2000 \mathrm{~m}^{2}$ \\
\hline CO 4 grass & $1800 \mathrm{~m}^{2}$ \\
\hline Dairy unit & 2 cows \\
\hline Poultry shed & 50 desi birds \\
\hline Vermicompost & 2 units \\
\hline Total area & $\mathbf{1 0 , 0 0 0} \mathbf{~ m}^{\mathbf{2}} \mathbf{( 1}$ ha) \\
\hline
\end{tabular}

Table.2 Experimental details of integrated farming system

\begin{tabular}{|l|c|c|c|c|}
\hline \multicolumn{1}{|c|}{ Crop } & \multicolumn{2}{|c|}{ Date of planting/ sowing } & Variety & Irrigation based on \\
& First year & Second year & & IW/CPE ratio \\
\hline Sugarcane & 06.04 .2015 & 06.05 .2016 & CO 86032 & $\mathbf{0 . 7 5}$ \\
\hline Banana & 26.02 .2015 & 20.02 .2016 & Kathali & $\mathbf{1 . 0}$ \\
\hline Turmeric & 17.06 .2015 & 14.06 .2016 & BSR 2 & $\mathbf{0 . 9}$ \\
\hline Maize & 13.02 .2015 & 05.06 .2016 & CO 6 & $\mathbf{0 . 8}$ \\
\hline Cumbu Napier & $\mathbf{3 0 . 0 2 . 2 0 1 5}$ & $\mathbf{1 8 . 0 3 . 2 0 1 6}$ & CO $(\mathbf{C N}) 4$ & once in ten days \\
\hline
\end{tabular}


Table.3 Water productivity of gardenland IFS and CFS (Average of two year)

\begin{tabular}{|l|c|c|c|c|}
\hline \multicolumn{1}{|c|}{ Enterprises } & Area (ha) & $\begin{array}{c}\text { Water usage } \\
\mathbf{( m}^{\mathbf{3}}\end{array}$ & Unit Yield (kg) & $\begin{array}{c}\text { Physical } \\
\text { WP(kgm }\end{array}$ \\
\hline Integrated Farming System (IFS) & & & \\
\hline Sugarcane & 0.2 & 2866 & 22250 & 7.77 \\
\hline Banana & 0.2 & 3174 & 3325 & 1.05 \\
\hline Turmeric & 0.2 & 2047 & 5338 & 2.61 \\
\hline Maize & 0.2 & 1076 & 1258 & 1.18 \\
\hline Fodder sorghum & & 2039 & 5450 & 2.67 \\
\hline Cumbu napier grass & 0.18 & 2942 & 2942 & 18.44 \\
\hline Dairy & 2 Nos. & 99.12 & 5017 lit & 50.61 \\
\hline Poultry & 50 Nos. & 1.49 & 148 & 99.02 \\
\hline Vermicompost & 2 units & 4.48 & 1805 & 403.30 \\
\hline Total (1 ha) & & $\mathbf{1 4 2 4 9}$ & $\mathbf{1 1 7 7 8 4}$ & $\mathbf{8 . 2 6}$ \\
\hline Conventional Farming System (CFS) & & & \\
\hline Rice & 1 & 11655 & 5225 & 0.45 \\
\hline Groundnut & 1 & 5275 & 1343 & 0.25 \\
\hline Maize & 1 & 5995 & 5488 & 0.92 \\
\hline Total (1 ha) & & $\mathbf{2 2 9 2 5}$ & $\mathbf{1 2 0 5 5}$ & $\mathbf{1 . 6 2}$ \\
\hline
\end{tabular}

Table.4 Economics of gardenland IFS and CFS (Average of two year)

\begin{tabular}{|c|c|c|c|c|c|}
\hline Enterprises & Area (ha) & $\begin{array}{l}\text { Water usage } \\
\qquad\left(\mathbf{m}^{3}\right)\end{array}$ & $\begin{array}{c}\text { Unit } \\
\text { Yield (kg) }\end{array}$ & $\begin{array}{c}\text { Gross Income } \\
\text { (Rs.) }\end{array}$ & $\begin{array}{c}\text { Economic } \\
\text { WP(Rs.m } \\
\left.\mathbf{3}_{\mathbf{3}}\right)\end{array}$ \\
\hline \multicolumn{6}{|c|}{ Integrated Farming System (IFS) } \\
\hline Sugarcane & 0.2 & 2866 & 22250 & 52581 & 18.35 \\
\hline Banana & 0.2 & 3174 & 3325 & 116375 & 36.70 \\
\hline Turmeric & 0.2 & 2047 & 5338 & 64056 & 31.31 \\
\hline Maize & \multirow[t]{2}{*}{0.2} & 1076 & 1258 & 16348 & 15.33 \\
\hline Fodder sorghum & & 2039 & 5450 & 8175 & 4.01 \\
\hline $\begin{array}{l}\text { Cumbu Napier } \\
\text { grass }\end{array}$ & 0.18 & 2942 & 2942 & 81365 & 27.66 \\
\hline Dairy & 2 Nos. & 99.12 & 5017 lit & 175595 & 1771.51 \\
\hline Poultry & 50 Nos. & 1.49 & 148 & 29500 & 19803.92 \\
\hline Vermicompost & 2 units & 4.48 & 1805 & 18050 & 4032.96 \\
\hline Total (1 ha) & & 14249 & 117784 & 562044 & 39.44 \\
\hline \multicolumn{6}{|c|}{ Conventional Farming System (CFS) } \\
\hline Rice & 1 & 11655 & 5225 & 78375 & 6.74 \\
\hline Groundnut & 1 & 5275 & 1343 & 67125 & 12.69 \\
\hline Maize & 1 & 5995 & 5488 & 71338 & 11.93 \\
\hline Total (1 ha) & & 22925 & 12055 & 216838 & 9.46 \\
\hline
\end{tabular}




\section{Economics of integrated farming system}

Economic analysis of technology clearly showed advantage over conventional system of cropping under rainfed conditions. A net profit of about $200 \%$ of the total cost indicates the economic viability of the technology. It has considerable potential to provide food security, nutritional benefits, employment generation and providing additional income to resource poor small farmers. Ramrao et al., (2006) studied croplivestock integrated farming system for the marginal farmers in rainfed regions of Chhattisgarh in Central India to find out a sustainable mixed farming model which is economically viable integrating the different component like crop, livestock, poultry and duck on 1.5- acre land holding.

The inclusion of animal component in the system set a positive link on sustainability by generating cash income, improving family nutrition and recycling crop residues and livestock refuse into valuable nutrient source for crops (Saxena et al., 2003). Integration of livestock with crops on watershed and individual holding basis has been reported to improve the traditional farming system on sustainable and eco-friendly basis (Dhiman et al., 2003).

From the Table 4, the higher gross income of Rs. 562044/- recorded under IFS compared to CFS (Rs.216838/-). In gardenland situation, the higher economic water productivity $\left(39.44 \mathrm{Rs}^{-3} \mathrm{~m}^{-3}\right)$ were recorded in IFS compared to CFS $\left(9.46 \mathrm{Rs}^{-3} \mathrm{~m}^{-3}\right)$. This might be due to efficient utilisation of resources.

In Haryana, Sheokand et al., (2000) conducted studies of various farming systems on 1 ha of irrigated and 1.5 ha of unirrigated land and found that under irrigated conditions of mixed farming with crossbred cows yielded the highest net profit (Rs. 20581) followed by mixed farming with buffaloes (Rs.6218) and lowest in arable farming (Rs. 4615). In another study conducted with 240 farmers of Rohtak (wheat-sugarcane), Hisar (wheat-cotton) and Bhiwani (chickpea-pearl millet) districts in Haryana which represented zones of different crop rotations revealed that maximum returns of Rs.12593, 6746 and 2317/ha was obtained from 1 ha with buffaloes in Rohtak, Hisar and Bhiwani, respectively. The highest net returns from Rohtak was attributed to the existence of a better soil fertility type and of irrigation facilities coupled with better control measures compared to other zones. Livestock also constitutes "living bank" providing flexible financial reserve in times of emergency and serve as "insurance" against crop failure for survival (Ramrao et al., 2005).

In conclusion the results of water productivity in integrated farming system in western zone of Tamil Nadu revealed that the gardenland IFS recorded lower water consumed (14249 $\mathrm{m}^{3}$ ) compared to conventional farming system $\left(22925 \mathrm{~m}^{3}\right)$. The higher gross income of Rs.562044/-, physical water productivity $\left(8.26 \mathrm{kgm}^{-3}\right)$ and economic water productivity (39.44 Rs. $\mathrm{m}^{-3}$ ) recorded under IFS compared to CFS. It is concluded from the study that Integrated Farming system favourably influenced the yield which resulted in higher irrigation water productivity against lower amounts of water applied. Moreover it indicated that Integrated Farming system in gardenland situation is economically significant.

\section{References}

Bakker M, Barker R, Meinzen-Dick R, Flemming K. 1999. Eds. Multiple uses of water in irrigated areas. A case study frorm Sri Lanka, SWIM paper 8, Internet Water Management Institute, Colombo, Sri Lanka. 
Bastiaanssen WGM, Van Dam JC, Droogers P. 2003. Introduction. In: van Dam JC, Malik RS (eds) Water productivity of irrigated crops in Sirsa district, India. International Water Management Institute, Sri Lanka, pp 11-20

CWC. 2018. Water and Related Statistics, Central Water Commission, Ministry of Water Resources, Government of India

Dhiman K R, Bujarbaruah K M and Satapathy K K. 2003. Integrated farming system for sustainable development ofrainfed agriculture in North Eastern region. (In) Proceedings of International Conference on World Perspective on Short Rotation Forestry for Industrial and Rural Development, held during 7 13 September 2003 at Solan, Himachal Pradesh, p 154.

Gill MS, Samra JS, Singh G. 2005. Integrated farming system for realizing high productivity under shallowwater table conditions. Research Bulletin of Punjab Agriculture University, Ludhiana.

Molden D, Murray-Rust H, Sakthivadivel R, Makin I. 2003. A water productivity framework for understanding and action. In: Kijne JW, Barker R, Molden $\mathrm{D}$ (eds) Water productivity in agriculture: limits and opportunities for improvement. CABI Publishing, Wallingford, pp. 1-18.

Molden D. 1997. Accounting for Water Use and Productivity. SWIM Paper 1. International Irrigation Management Institute, Colombo, Sri Lanka, p 26.

Ramrao W Y, Tiwari S P and Singh P. 2005. Crop-livestock integrated farming system for augmenting socio-economic status of smallholder tribal of Chhattisgarh in central India. Livestock Research for Rural Development, Vol 17 , Article\#90. http://www.lrrd.org/lrrd17/8/ramr1709 O.htm

Ramrao W Y, Tiwari S P and Singh P. 2006. Crop-livestock integrated farming system for the marginal farmers in rainfed regions of Chhattisgarh in central India. Livestock Research for Rural development. 18 (7): Article \# 102. http://www.lrrd. org/lrrd18/7/ramr18102.htm

Saxena D C, Singh N P, Satapathy K K, Panwar A S and Singh J L. 2003. Sustainable farming systems for hill agriculture. (In) Proceeding of National Seminar 'Approaches for Increasing Agricultural Productivity in Hill and Mountain Ecosystem', held during 1820 October, 2001at Barapani, pp 73-85.

Sharda VN, Juyal GP. 2007. Rainwater harvesting, ground water recharge and efficient use in high rainfall areas. Souvenir. pp 59-70. Ensuring water and environment for prosperity and posterity. 10th Inter- Regional conference on Water and environment, 17-20 October, 2007.

Sheokand R S, Narinder S and Sheoran O P. 2000. Comparative economics of different farming systems under paddywheat farming sequence in rice-belt of Haryana. Haryana Agricultural University Research Journal 30(1/2): 49-53.

\section{How to cite this article:}

Bhuvaneswari, J., G. Thiyagarajan, M. Manikandan, S. K. Natarajan and Thenmozhi, S. 2020. Multiple Water Use in Gardenland Integrated Farming System for Enhancing Productivity. Int.J.Curr.Microbiol.App.Sci. 9(11): 2151-2156. doi: https://doi.org/10.20546/ijcmas.2020.911.255 